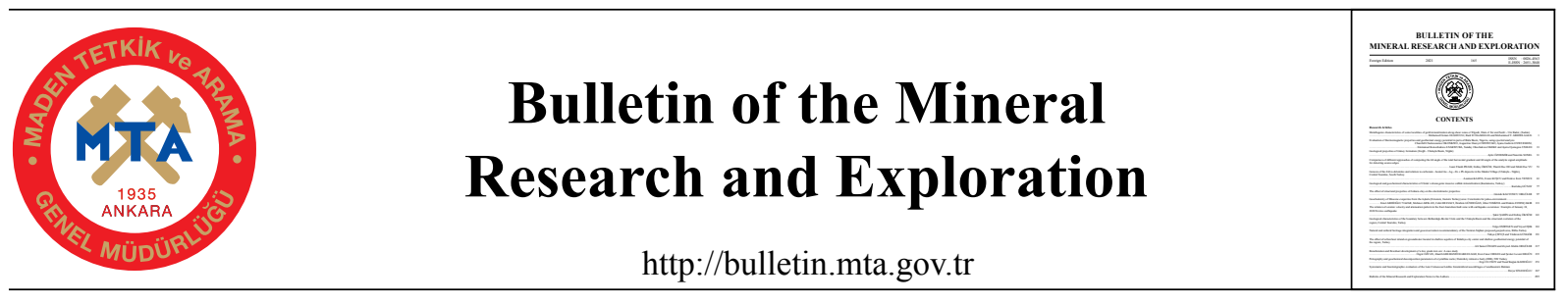

\title{
Evaluation of thermomagnetic properties and geothermal energy potential in parts of Bida Basin, Nigeria, using spectral analysis
}

\author{
Churchill Chukwunonso OKONKWO ${ }^{\mathrm{a} *} \mathbb{D}$, Augustine Ifeanyi CHINWUKO ${ }^{\mathrm{b}} \mathbb{D}$, Ajana Godwin ONWUEMESI ${ }^{\mathrm{b}}$, \\ Emmanuel Kenechukwu ANAKWUBA $^{\mathrm{b}} \mathbb{\oplus}$, Sunday Okechukwu OKEKE ${ }^{\mathrm{a}} \mathbb{D}$ and Ayatu Ojonugwa USMANc $\mathbb{D}$ \\ ${ }^{\text {a }}$ Federal College of Education Umunze, Department of Physics, Nigeria \\ ${ }^{\mathrm{b}}$ Nnamdi Azikiwe University, Department of Geological Sciences, Awka, Nigeria \\ ${ }^{\mathrm{c}}$ Alex Ekwueme Federal University, Department of Physics / Geology / Geophysics, Ndufu - Alike, Ebonyi, Nigeria
}

Research Article

Keywords:

Lineament, Rose

Diagram, Magnetic

Sources, Curie Isotherm,

Thermal Properties.
Received Date: 16.04.2020 Accepted Date: 17.09.2020

\begin{abstract}
Thermomagnetic properties and geothermal energy potential in parts of Bida Basin, Nigeria have been evaluated using spectral analysis of integrated nine aeromagnetic data. The study area covering $27.225 \mathrm{~km}^{2}$ of aeromagnetic data was examined and construed in order to delineate the thermal properties of the country-rock in the area. The result of the visual inception of the residual map reveals that the area comprises an extremely irregular pattern of magnetic intensities that range from 220 to $240 \mathrm{nT}$. Two structural features of folding evidence were also delineated in the area namely; uplift and depression. The result of the lineament structures from the shaded relief map and Rose diagram depicts NE-SW as the major trend with the minor trend is NW - SE. Two depths to magnetic sources were distinguished in the area: the shallower bodies which vary from 1.27 to 1.96 $\mathrm{km}$ and the deeper bodies that vary from 2.01 to $4.27 \mathrm{~km}$. The result also shows an average depth to the centroid as $12.97 \mathrm{~km}$ in the area. The thermomagnetic properties analysis show average values of $23.12 \mathrm{~km}$ Curie isotherm, $25.27{ }^{\circ} \mathrm{C} / \mathrm{km}$ geothermal gradients and $63.17 \mathrm{mWm}^{2}$ heat flow in the area. The study concludes that the study area possesses good potential quality for geothermal energy generation and exploration.
\end{abstract}

\section{Introduction}

The major problem threatening the Nigerian economic space is the epileptic power supply situation in the country and gap in accessing information on alternative energy resources. The capacity of Nigeria to adequately cater for the energy demands of its ever growing population is seriously inadequate if further effort is not invested in the search for renewable, sustainable and cleaner energy resources capable of meeting this growing demand. Therefore, there is great need to investigate and harness the geothermal energy potentials for satisfaction of the nations energy needs especially around the fields of lighting, transportation, communication and others.

Accordingly, recent researches have shown that the geothermal energy sources are viable in those regions that were underlain by basement rocks, which comprises metamorphic and igneous rocks that were formed from the interior part of the earth (Chukwu et al., 2017; Abraham et al., 2014; Anakwuba and Chinwuko, 2015). Surprisingly, two-third of Nigeria

Citation Info: Okonkwo, C. C., Chinwuko, A. I., Onwuemesi, A. G., Anakwuba, E. K., Okeke, S. O., Usman, A. O. 2021. Evaluation of thermomagnetic properties and geothermal energy potential in parts of Bida Basin, Nigeria, using spectral analysis. Bulletin of the Mineral Research and Exploration 165, 13-30. https://doi.org/10.19111/bulletinofmre.796381

*Corresponding author: Churchill Chukwunonso OKONKWO, chukschurchill@yahoo.com 
land mass is covered by these rock types, but little or no attention has been paid to the chase for geothermal energy exploration. As a result, there has been a gap in thermomagnetic properties information within Nigeria and the study area is no exception. Furthermore, considering the environmental impact of petroleum products during and after exploration couple with decline in oil and gas production in our country, it has become imperative for our nation to explore the alternative source of energy called geothermal energy in order to meet our energy needs.

However, thermomagnetism can be defined as the magnetism that originated from the action of heat or caused by the action of heat within the subsurface. Thermomagnetic properties such as Curie isotherm depth, subsurface geothermal gradient and heat flow are essential in exploration of geothermal energy. According to several authors (Burke, 1972; Chinwuko et al., 2012; Okonkwo et al., 2012; Abraham et al., 2014; Abraham et al., 2015; Biswas et al., 2017; Chukwu et al., 2017), the palaeomagnetic signal of rocks (including the thermomagnetic properties) occurs primarily due to the existence of iron - bearing oxide solid solutions with the spinel crystal structure (like titanomagnetites). These authors also established that there are possibilities of these minerals to obtain strong and stable remanent magnetization due to the presence of Curie temperature, saturation magnetization, and remanence properties of the rock based on their fundamental crystal chemical state and microstructure of minerals. Actually, the thermomagnetic properties evaluation is a geophysical method which can serve the purpose of geothermal data in such areas where borehole data are absent or missing, and the study area is no exception (Bhattacharyya and Leu, 1975; Ross et al., 2006; Saibi et al., 2015; Biswas, 2015; Singh and Biswas, 2016; Biswas and Sharma, 2016,).

Consequently, this research focuses on the evaluation of thermomagnetic characteristics of rock units in order to deduce the geothermal energy potential of parts of Southern Bida Basin, Nigeria, through the use of spectral analysis technique. This approach will outline the anomalous bodies across the area through estimation of the depth to magnetic sources, the depth to the centroid and crustal temperature information in the area of study. The study will also ascertain the lineament patterns along with the real view of the Basin. The researchers are optimistic that this research will contribute to the vast potential of Nigeria's untapped, renewable and sustainable energy resources and heat flow information.

\subsection{Geographic and Geologic Background}

Geographically, the area under investigation lies between latitudes $8^{\circ} 00-9^{\circ} 30^{\prime} \mathrm{N}$ and longitudes $5^{\circ} 30-7^{\circ} 00^{\prime} \mathrm{E}$ (Figure 1) with an areal extent of $27.225 \mathrm{~km}^{2}$. Geologically, the area is situated within the Southern Bida Basin, Nigeria and it is associated with sedimentary terrain which comprises alluvium deposits of Cenezoic Era. However, the Basement Complex rock intruded within and around the study area account for the great fracturing observed in the area. According to Adeleye (1974) and Obaje et al. (2013), the Bida Basin sometimes referred to as Nupe Basin can be classified as an intracratonic sedimentary basin that trend in NW - SE direction and it widens from Niger State precisely Kontagora to regions feebly outside Lokoja region of Kogi State in the southern part.

Notwithstanding, the stratigraphic successions of the southern Bida Basin in Figure 1, reveals that the Lokoja Formation being the oldest material is overlain by the Patti Formation which is as well overlain by the Agbaja ironstone Formation (Obaje et al., 2013; Ojo and Akande, 2012). According to some authors, the Campanian Nkporo and Enugu Formations of northern Anambra Basin have some lateral equivalents with the Lokoja Formation (Ojo and Akande, 2012). Also, the Mamu Formation of Anambra Basin possesses some lateral equivalents with three formations of Bida Basin namely; Patti, Bida and Lokoja Formations. More so, the Ajalli sandstones which are member of Ajalli Formation have its laterally equivalent in the Bida Basin as the Patti Formations (Ikumbur et al., 2013; Obaje et al., 2013; Ojo and Akande, 2012).

\section{Research Methodology}

The method applied in this research involved the use of nine (9) aeromagnetic data sheets: 183 (Egbako), 184 (Bida), 185 (Paiko), 204 (Pategi), 246 (Baro), 206 (Gulu), 225 (Isanlu), 226 (Aiyegunle) and 227 (Kotonkarfi) (Figure 2). These data were obtained from Nigeria Geological Survey Agency (NGSA), which were integrated to generate a total magnetic 


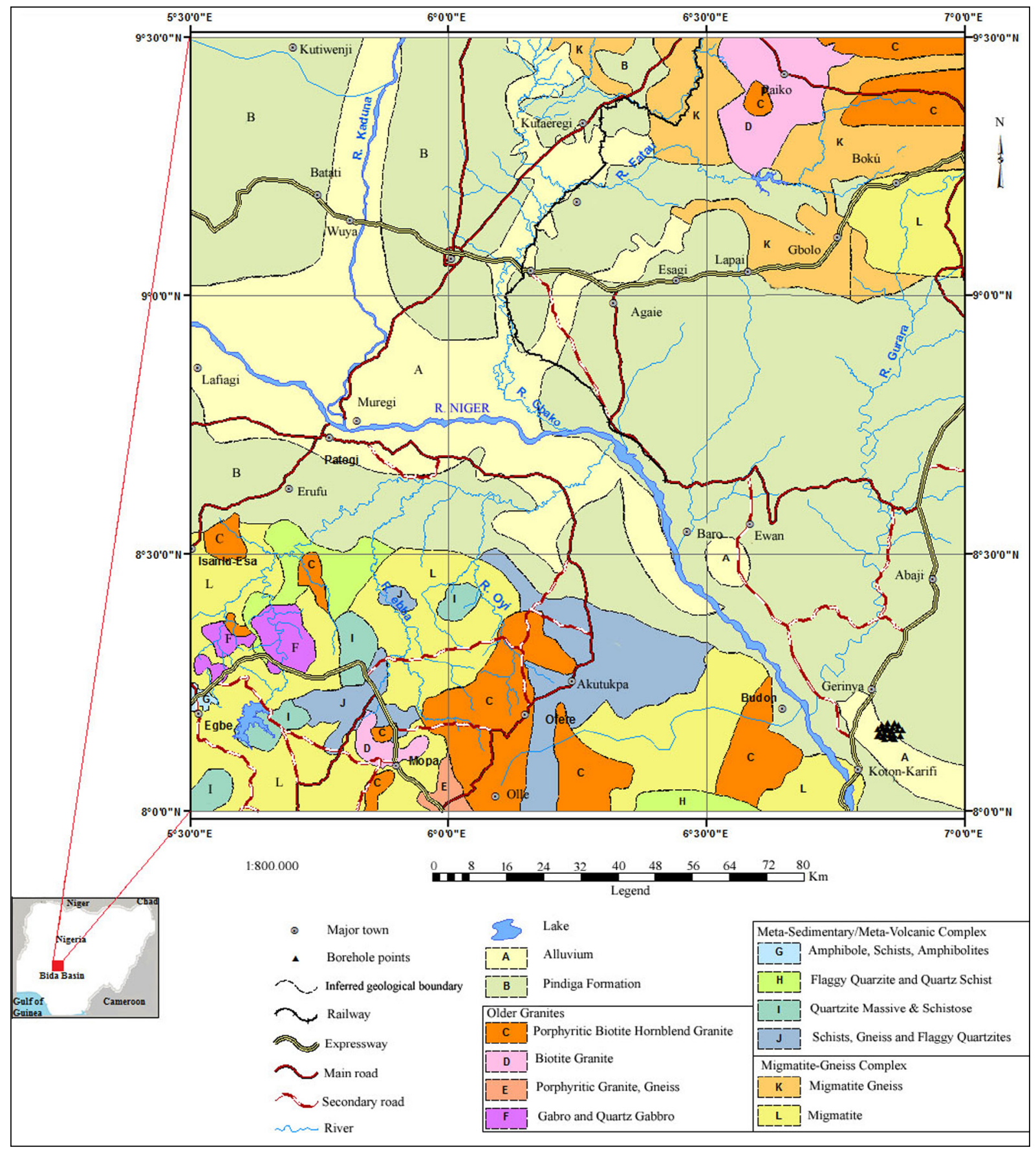

Figure 1- Local geological map of the study area (modified after Obaje et al., 2013 and Petters,1978).

intensity map (Figure 3) and the residual data were analyzed with the aid of spectral analysis. The visual inception analysis was carried out on the magnetic maps based on magnetic closures and lineament delineation through the azimuth direction of the structural lineaments. With the aid of shaded relief maps produced from four different horizontal position light angles - $\operatorname{HPLA}\left(0^{\circ}, 45^{\circ}, 90^{\circ}\right.$, and $\left.135^{\circ}\right)$ at constant vertical position light angle - VPLA $\left(0^{\circ}\right)$, paved way for perfect delineation of lineament orientation across the area. The result of lineament delineation serves as key parameters that were keyed into the Grapher - 5 software package in order to generate a Rose diagram for the area.

More so, the integrated data which became the total magnetic intensity (TMI) data (Figure 3) were subjected to filtering using a generated linear trend 


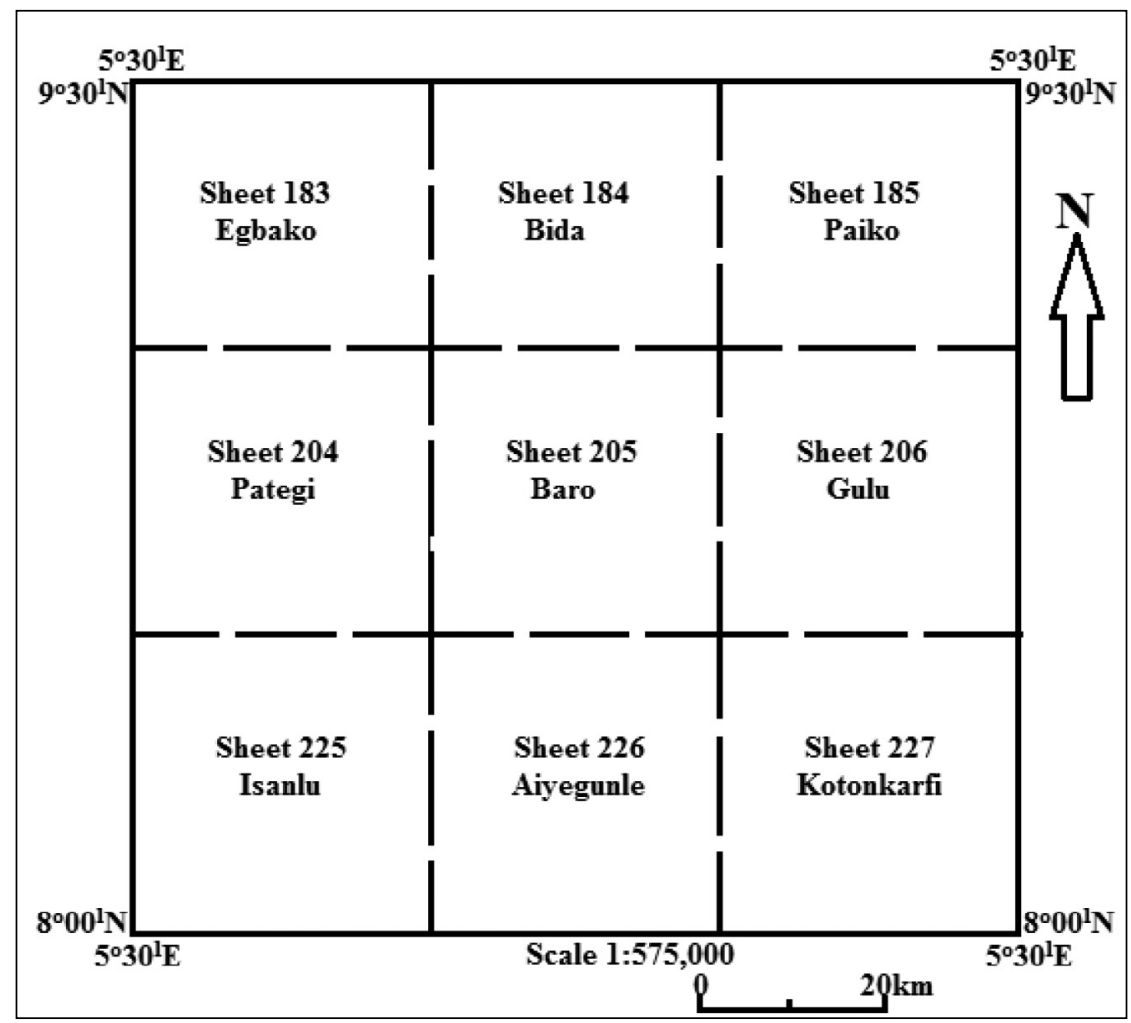

Figure 2- Acquired nine sheets of aeromagnetic data.

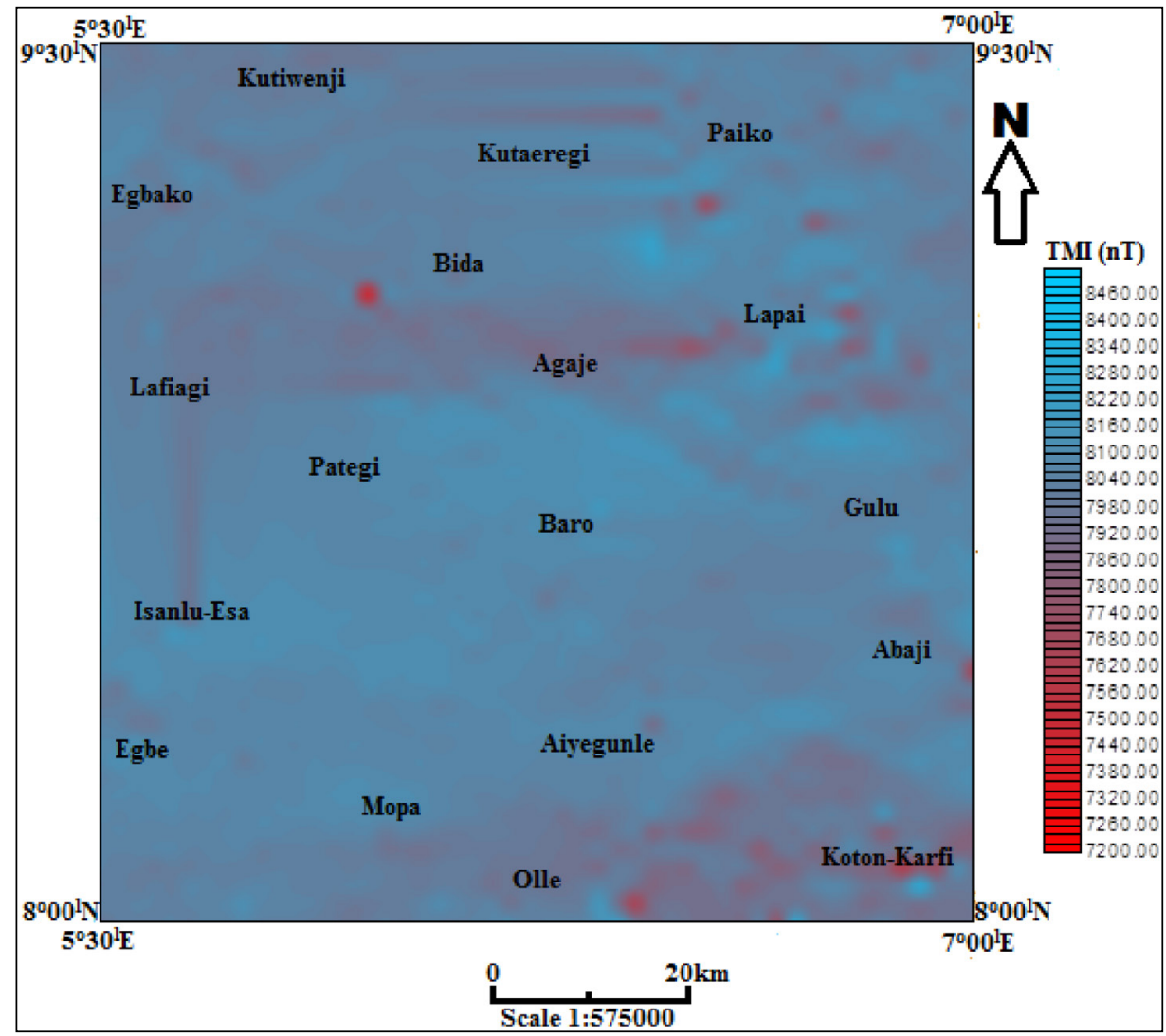

Figure 3- TMI map of Bida and its environments (contour interval $\sim 20 \mathrm{nT}$ ). 
surface (equation 1) of the multiple regression techniques as discussed by previous authors (Spector and Grant, 1970; Chinwuko et al., 2012; Ikumbur et al., 2013; Chinwuko et al., 2014). This filtering was carried out in order to separate both the regional and residual magnetic anomalies.

$S(a, b)=1452.07 b-77.08 a-4658.08$

Where, $\mathrm{S}(\mathrm{a}, \mathrm{b})=$ the regional value; $\mathrm{a}=$ the latitude and $b=$ the longitude.

In addition, the regional trend surface data obtained were deducted from the total magnetic field intensity data in order to generate the residual magnetic data (Figure 4). Thus, the residual anomaly data were subjected to spectral analysis in order to obtain the depth to magnetic sources and thermal properties within the area. The spectral analysis is a mathematical tool associated with Discrete Fourier Transform method which has been described and used by some many authors such as Spector and Grant (1970), Bhattacharyya and Leu (1975), Onwuemesi (1995), Onwuemesi (1997), Chinwuko et al. (2014), Pamukçu et al. (2014) and others.
Subsequently, the result of the spectral analysis was used to compute depth to the magnetic sources; delineate Curie isotherm depth, geothermal gradient along with mantle heat flow (see equations 2, 3 and 4). Immediately after obtaining the main amplitude, the next was to obtain the gradient of the linear segments of the first and second longest wavelengths of the spectrum as discussed by previous authors (Bhattacharyya, 1966; Bhattacharyya and Leu, 1975; Okubo et al., 1985; Tanaka et al., 1999; Nwankwo and Ekine, 2010; Frashëri et al., 2011; Mandal et al., 2013; Abraham et al., 2015; Singh and Biswas, 2016; Ojonugwa et al., 2018).

Then, the basal depth of the magnetic source or Curie depth $\left(Z_{b}\right)$ was calculated from the equation of Bhattacharyya and Leu, (1975) that contains the depth to centroid $\left(Z_{o}\right)$ and the depth to the top boundary $\left(Z_{t}\right)$ as shown in equation 1 below:

$Z_{b}=2 Z_{o}-Z_{t}$

According to Tanaka et al. (1999), Curie temperature $(\theta)$ can be obtained from the Curie point depth $\left(Z_{b}\right)$ and the geothermal gradient $(d T / d Z)$ using

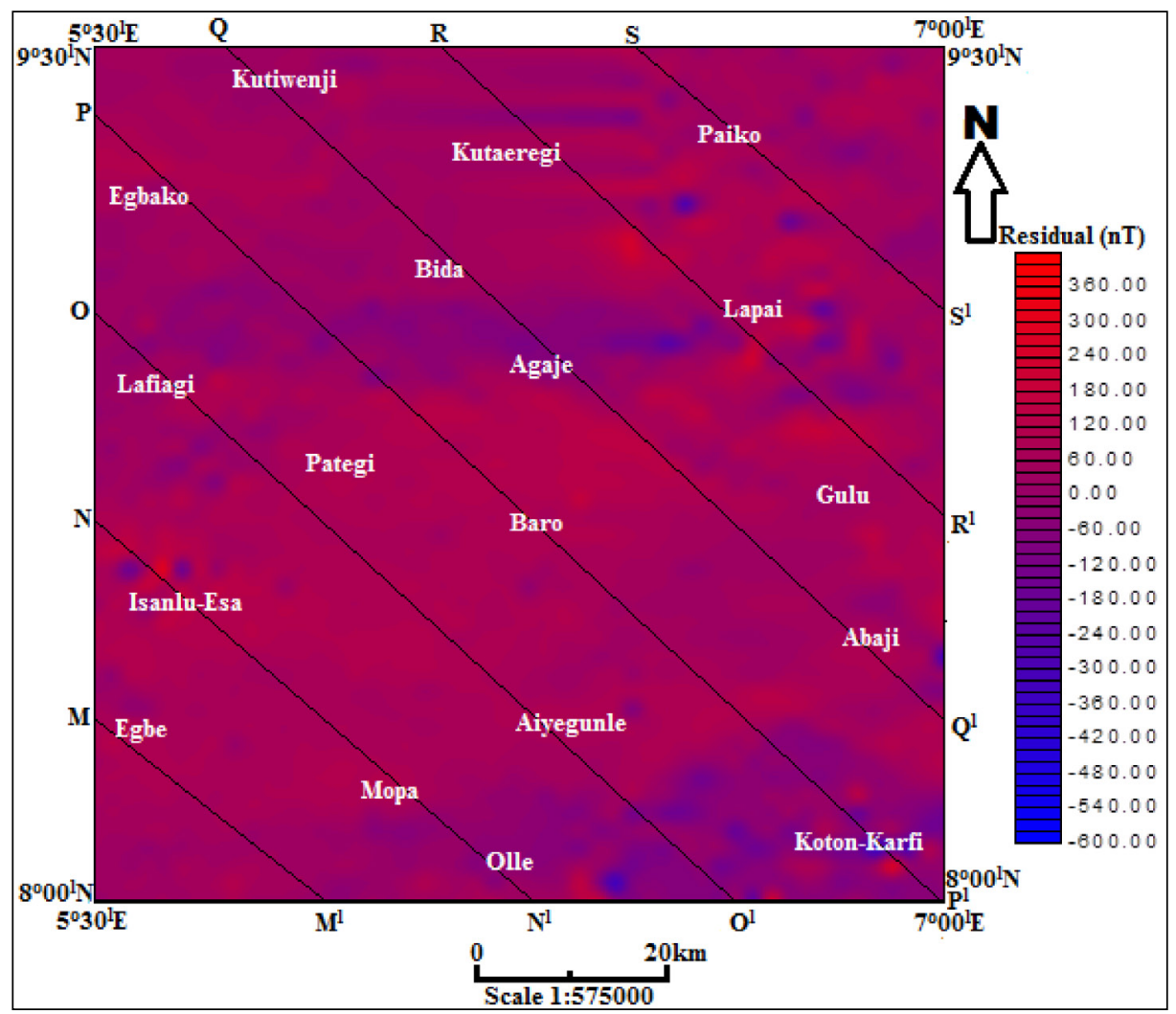

Figure 4- Residual map of Bida and its environments (contour interval $\sim 20 \mathrm{nT}$ ). 
equation 2, provided that there are no heat sources or sinks between the earth's surface and the Curie point depth.

$\theta=\left[\frac{d T}{d Z}\right] Z_{b}$

More so, Tanaka et al. (1999) established a mathematical relationship between the Curie point depth $\left(Z_{b}\right)$ and the heat flow $(q)$ as shown in equation 3:

$\mathrm{q}=\lambda\left[\frac{\theta}{z_{b}}\right]$

In this research, the Curie point temperature $(\theta)$ of $580{ }^{\circ} \mathrm{C}$ and thermal conductivity $(\lambda)$ of $2.5 \mathrm{Wm}^{-10} \mathrm{C}^{-1}$ as average for igneous rocks were used as standard according to Nwankwo et al., 2010.

All the results obtained were used to generate distribution maps for all the key parameters in order to delineate the structural configuration within the area. Lastly, areas with geothermal energy potential were delineated using integrated geological and geophysical data.

\section{Findings and Interpretation}

\subsection{Visual Interpretation}

The visual assessment of total magnetic intensity and residual anomaly maps in the area depicts that there are complex patterns of magnetic signatures which consist of both small and lengthy wavelengths (Figures 3 and 4). According to Ikumbur et al. (2013), this variation in amplitude of the anomaly within the study area implies that there are evidence of different causative sources which are associated with various magnetic intensities, such as the magnetic intensity in the area which range from 7200 to $8460 \mathrm{nT}$ and -220 to 240 nT respectively. Around Paiko, Kutaeregi, Kotonkarfi, Bida, Lapai, Agaje, and Aiyegunle areas, the total magnetic intensity (TMI) and residual anomaly maps depict the underlying basement as having magnetic intensities. There are strong evidences of igneous intrusion when juxtaposed with the geologic map of the area. Indeed, these areas mentioned above possess mostly close - spaced contour lines and this implies that these areas are marked by numerous closed contours, which could serve as an indicative of igneous intrusions which usually contain aggregate of mineral deposits as evident in the study area like Koton - Karfi, Abaji, Bida and Paiko areas.

\subsection{Lineament Trend}

The major lineament structural trends defined from the shaded relief map (Figure 5) are NE - SW while the minor trends are visible along $\mathrm{E}-\mathrm{W}$ and NW - SE directions. The lineament trends obtained here is in confirmation with previous studies carried out within the Bida Basin and its surrounding Basement Complex (Ikumbur et al., 2013; Obaje, et al., 2013 and Ojonugwa et al., 2018). Juxtaposing these lineaments on the geological map of the area, it depicts that the lineament orientations are predominately within the area underlain by basement rocks compared with the area covered by sedimentary basin. Hence, the researchers can deduced that there are numerous tectonic activities going on within the area due to high concentration of structural lineaments across the area (Figure 5).

Furthermore, the structural configuration of the study area is also confirmed by the generated Rose diagram (Figure 6), in order ascertain the particular geologic age of rocks in the area as suggested by Anudu et al., (2012). As a result, the Rose diagram (Figure 6) has shown clearly that the prominent trends in the area are NE - SW and NNE - SSW, whereas, the minor trends occur along $\mathrm{E}-\mathrm{W}$ and NW - SE directions across the area. According to previous works such as, Ikumbur et al. (2013), Obaje et al. (2013), Anakwuba and Chinwuko, (2015) and Ojonugwa et al. (2018), three of the identified trends namely; NE - SW, NNE SSW and NW - SE within the study area are regarded as Pan - African Orogeny while the E - W might have occurred during the era of Pre - Pan - African Orogeny.

\subsection{Identification of Magnetic Anomaly}

In order to identify various anomalies across the study area, seven different profiles were taken on the residual anomaly map (Figure 4); $\mathrm{M}-\mathrm{M}^{1}, \mathrm{~N}-\mathrm{N}^{1}, \mathrm{O}$ $\mathrm{O}^{1}, \mathrm{P}-\mathrm{P}^{1}, \mathrm{Q}-\mathrm{Q}^{1}, \mathrm{R}-\mathrm{R}^{1}$ and $\mathrm{S}-\mathrm{S}^{1}$. These profiles were taken perpendicular to the direction of the magnetic anomalies. The profile results revealed a total of thirty nine (39) anomalies across the study area (Figure 7). The identified anomalies occur in peak and trough patterns and they are ranked from anomaly 1 - 39 (Figure 7).

\subsection{Depth to the Magnetic Sources}

The magnetic anomalies were subjected to spectral analysis in order to obtain the depth to the causative 


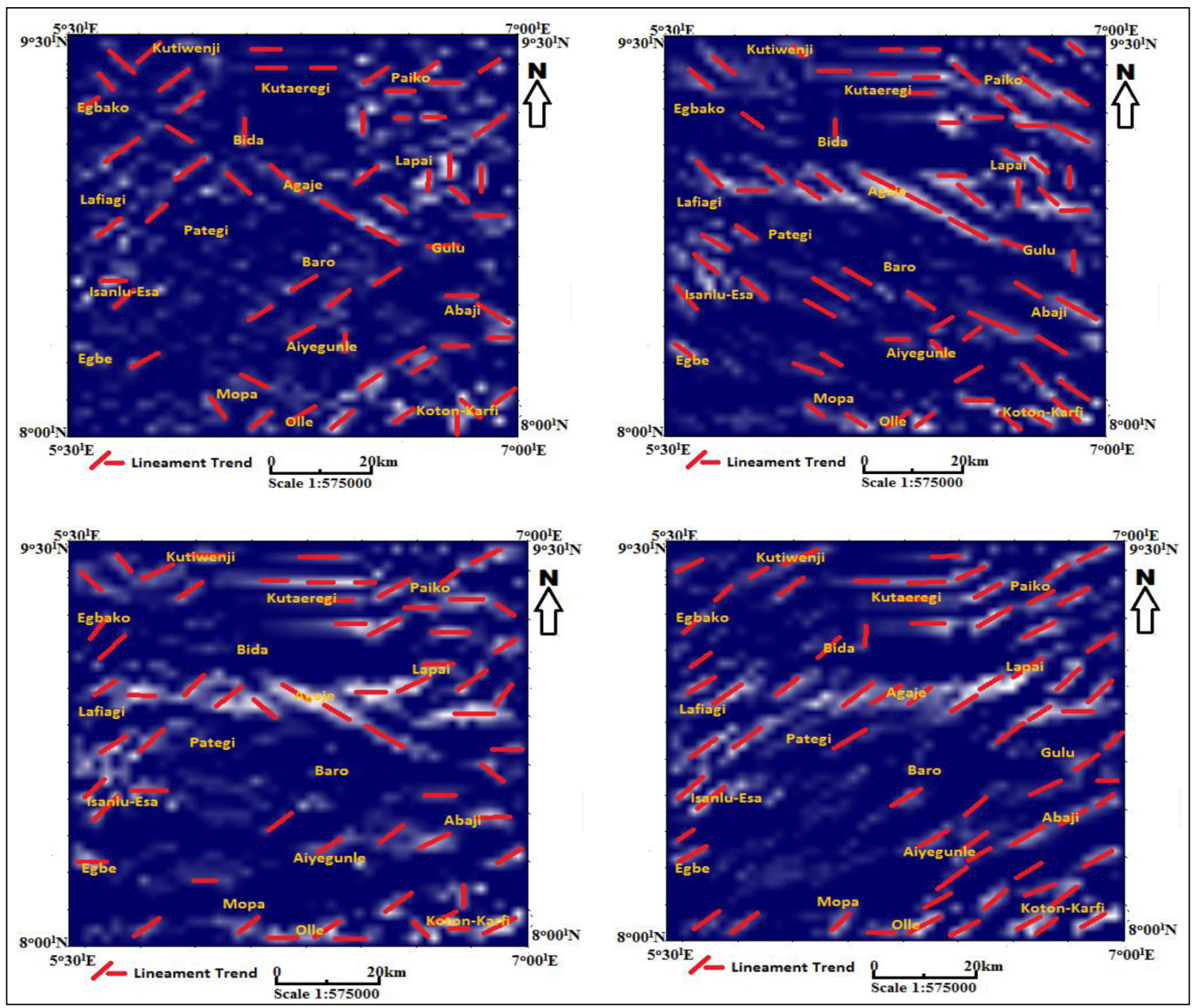

Figure 5- Shaded relief maps showing lineament trend in the area. a) HPLA- $0^{\circ}$ and VPLA- $0^{\circ}$, b) HPLA- $45^{\circ}$ and VPLA- $0^{\circ}$, c) HPLA $-90^{\circ}$ and VPLA- $-0^{\circ}$, d) HPLA $-135^{\circ}$ and VPLA $-0^{\circ}$.

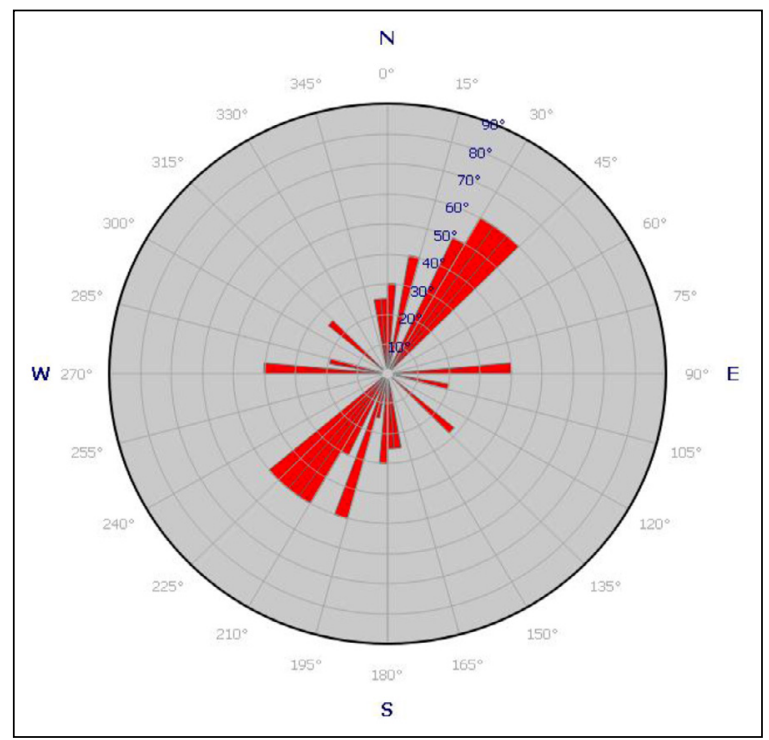

Figure 6- Rose diagram showing lineament trend across the study area. bodies or magnetic sources around the study area (Figure 8). The spectral analysis result depicts two magnetic sources, namely; the shallower bodies which vary from 1.27 to $1.96 \mathrm{~km}$ and the deeper bodies which vary from 2.01 to $4.27 \mathrm{~km}$ (Table 1 ). However, the depth to the centroid obtained through the spectral analysis depicts depth range from 9.79 to $15.75 \mathrm{~km}$ across the study area (Table 1).

Consequently, a basement relief map of the study area was produced using depth to the top of magnetic sources (Figure 9). The depth of basement is deeper in the southern and central part of the study area trending northwest - southeast direction whereas, at other parts of the area such as Kutawenji, Lafiaji, Koton - Karfi and Lapai areas have shallower sources (Figure 9). More so, the 3 - D surface plot of depth to the top of the magnetic sources shows presence of structural features such as peaks (uplifts) and depressions 


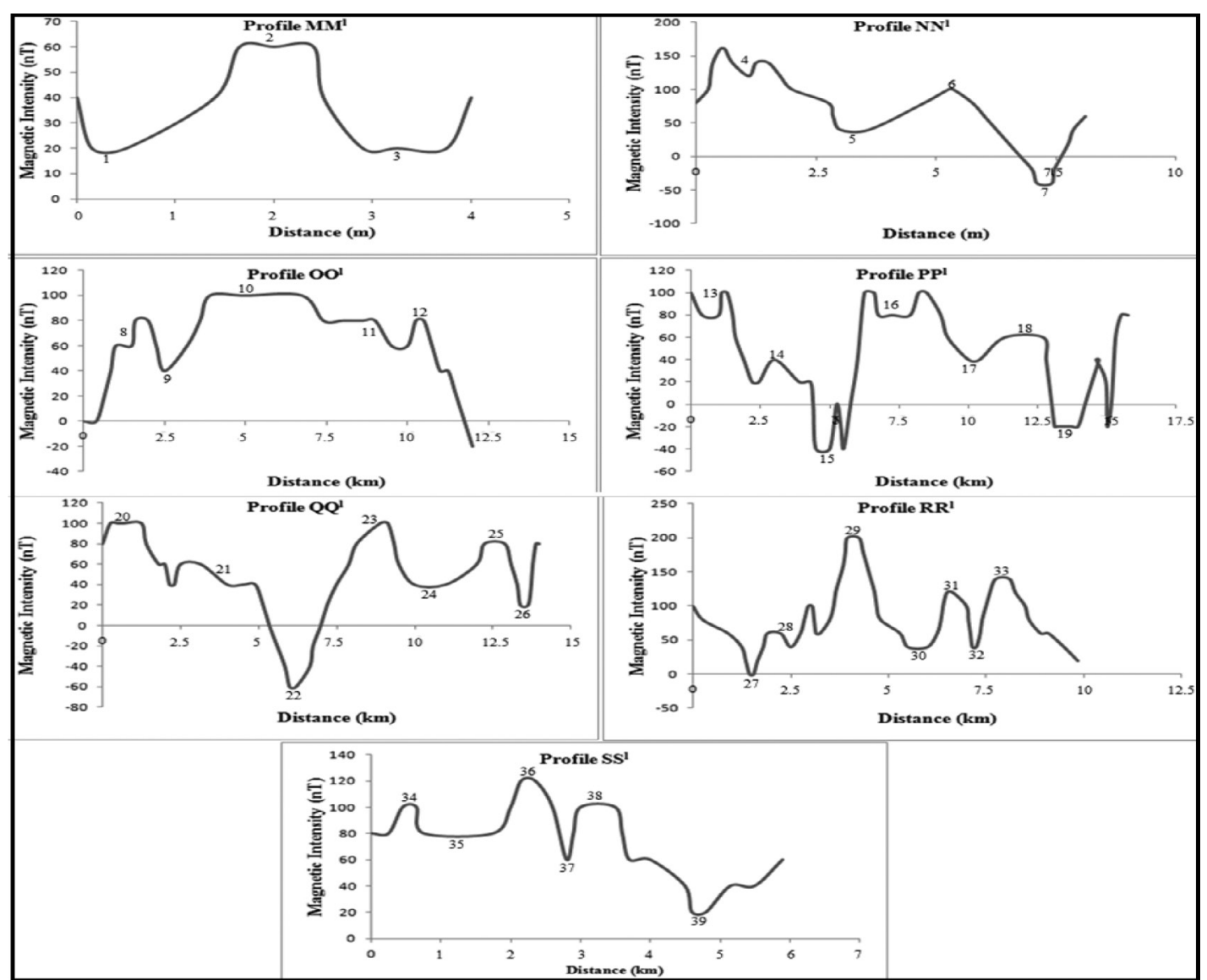

Figure 7- Graphs of profiles within the study area.

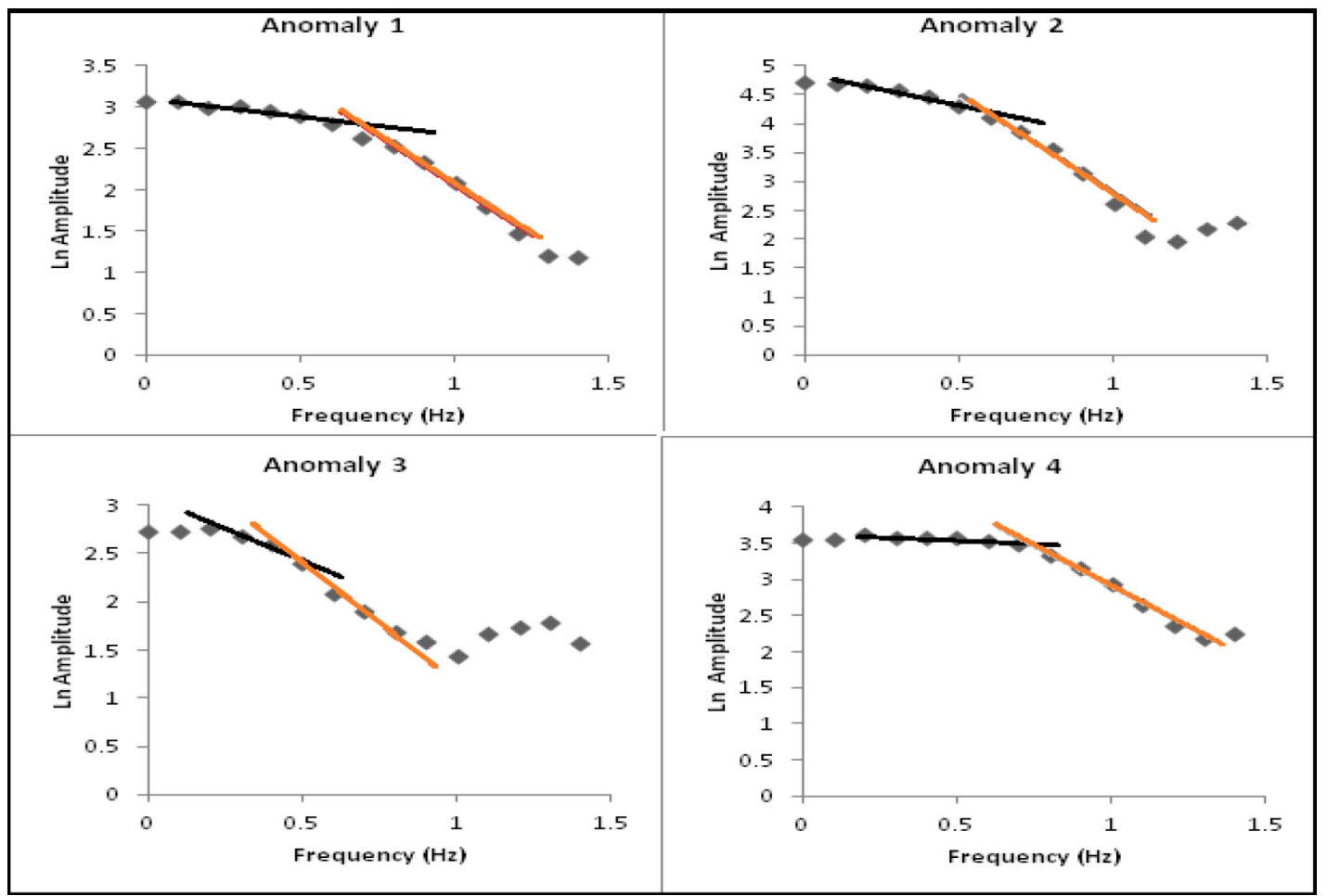

Figure 8- Representative spectral graph in the area. 
Table 1- Thermomagnetic parameters estimation from spectral analysis.

\begin{tabular}{|c|c|c|c|c|c|}
\hline & \multicolumn{2}{|c|}{ Spectral Analysis } & \multirow[b]{2}{*}{ Curie Depth $(\mathrm{km})$} & \multirow[b]{2}{*}{$\begin{array}{l}\text { Geothermal gradient } \\
\left({ }^{\circ} \mathrm{C} / \mathrm{km}\right)\end{array}$} & \multirow[b]{2}{*}{$\begin{array}{l}\text { Heat flow } \\
(\mathrm{mWm} 2)\end{array}$} \\
\hline Anomaly & Depth to the top $(\mathrm{km})$ & $\begin{array}{l}\text { Depth to the Centroid } \\
(\mathrm{km})\end{array}$ & & & \\
\hline 1 & 2.89 & 13.17 & 23.45 & 24.733 & 61.834 \\
\hline 2 & 3.4 & 12.04 & 20.68 & 28.046 & 70.116 \\
\hline 3 & 3.53 & 14.18 & 24.83 & 23.359 & 58.397 \\
\hline 4 & 1.27 & 12.53 & 23.79 & 24.380 & 60.950 \\
\hline 5 & 3.22 & 11.88 & 20.54 & 28.238 & 70.594 \\
\hline 6 & 3.47 & 14.24 & 25.01 & 23.191 & 57.977 \\
\hline 7 & 3.45 & 13.91 & 24.37 & 23.800 & 59.499 \\
\hline 8 & 2.58 & 12.36 & 22.14 & 26.197 & 65.492 \\
\hline 9 & 2.84 & 11.49 & 20.14 & 28.798 & 71.996 \\
\hline 10 & 3.59 & 15.75 & 27.91 & 20.781 & 51.953 \\
\hline 11 & 3.2 & 13.18 & 23.16 & 25.043 & 62.608 \\
\hline 12 & 1.96 & 12.29 & 22.62 & 25.641 & 64.103 \\
\hline 13 & 3.06 & 14.41 & 25.76 & 22.516 & 56.289 \\
\hline 14 & 3.55 & 13.98 & 24.41 & 23.761 & 59.402 \\
\hline 15 & 2.16 & 10.67 & 19.18 & 30.240 & 75.600 \\
\hline 16 & 3.23 & 11.94 & 20.65 & 28.087 & 70.2179 \\
\hline 17 & 4.09 & 13.86 & 23.63 & 24.545 & 61.363 \\
\hline 18 & 2.14 & 12.09 & 22.04 & 26.316 & 65.789 \\
\hline 19 & 4.27 & 14.21 & 24.15 & 24.017 & 60.041 \\
\hline 20 & 3.88 & 13.72 & 23.56 & 24.618 & 61.545 \\
\hline 21 & 2.31 & 12.88 & 23.45 & 24.733 & 61.834 \\
\hline 22 & 2.56 & 11.96 & 21.36 & 27.154 & 67.884 \\
\hline 23 & 3.89 & 12.75 & 21.61 & 26.839 & 67.099 \\
\hline 24 & 3.07 & 13.29 & 23.51 & 24.670 & 61.676 \\
\hline 25 & 3.74 & 13.15 & 22.56 & 25.709 & 64.273 \\
\hline 26 & 2.18 & 11.87 & 21.56 & 26.902 & 67.254 \\
\hline 27 & 2.56 & 14.33 & 26.1 & 22.222 & 55.556 \\
\hline 28 & 1.69 & 14.04 & 26.39 & 21.978 & 54.945 \\
\hline 29 & 1.73 & 12.81 & 23.89 & 24.278 & 60.695 \\
\hline 30 & 2.85 & 13.45 & 24.05 & 24.116 & 60.291 \\
\hline 31 & 2.01 & 13.21 & 24.41 & 23.761 & 59.402 \\
\hline 32 & 1.32 & 11.66 & 22 & 26.364 & 65.909 \\
\hline 33 & 2.84 & 10.79 & 18.74 & 30.950 & 77.375 \\
\hline 34 & 1.86 & 12.31 & 22.76 & 25.483 & 63.708 \\
\hline 35 & 2.92 & 13.18 & 23.44 & 24.744 & 61.860 \\
\hline 36 & 2.97 & 14.07 & 25.17 & 23.043 & 57.608 \\
\hline 37 & 1.73 & 11.45 & 21.17 & 27.397 & 68.493 \\
\hline 38 & 2.88 & 13.82 & 24.76 & 23.425 & 58.562 \\
\hline 39 & 3.16 & 12.99 & 22.82 & 25.416 & 63.541 \\
\hline Average & 2.82 & 12.97 & 23.12 & 25.277 & 63.173 \\
\hline
\end{tabular}

(troughs) within the area. Around Agaje, Egbako, Olle, Mopa and Abaji areas, there are visible linear depressions and these areas reveal higher sediments than the other parts such as Kutaeregi, Paiko, Lapai, Lafiagi, Aiyegunle, and Koton - Karfi areas which have prevalent uplifts (peaks) in conjunction with lower sedimentary thicknesses (Figure 10). The presence of these peaks (uplifts) suggests that there are numerous intrusive bodies around these areas; as a result, they are more tectonically active than the areas associated 


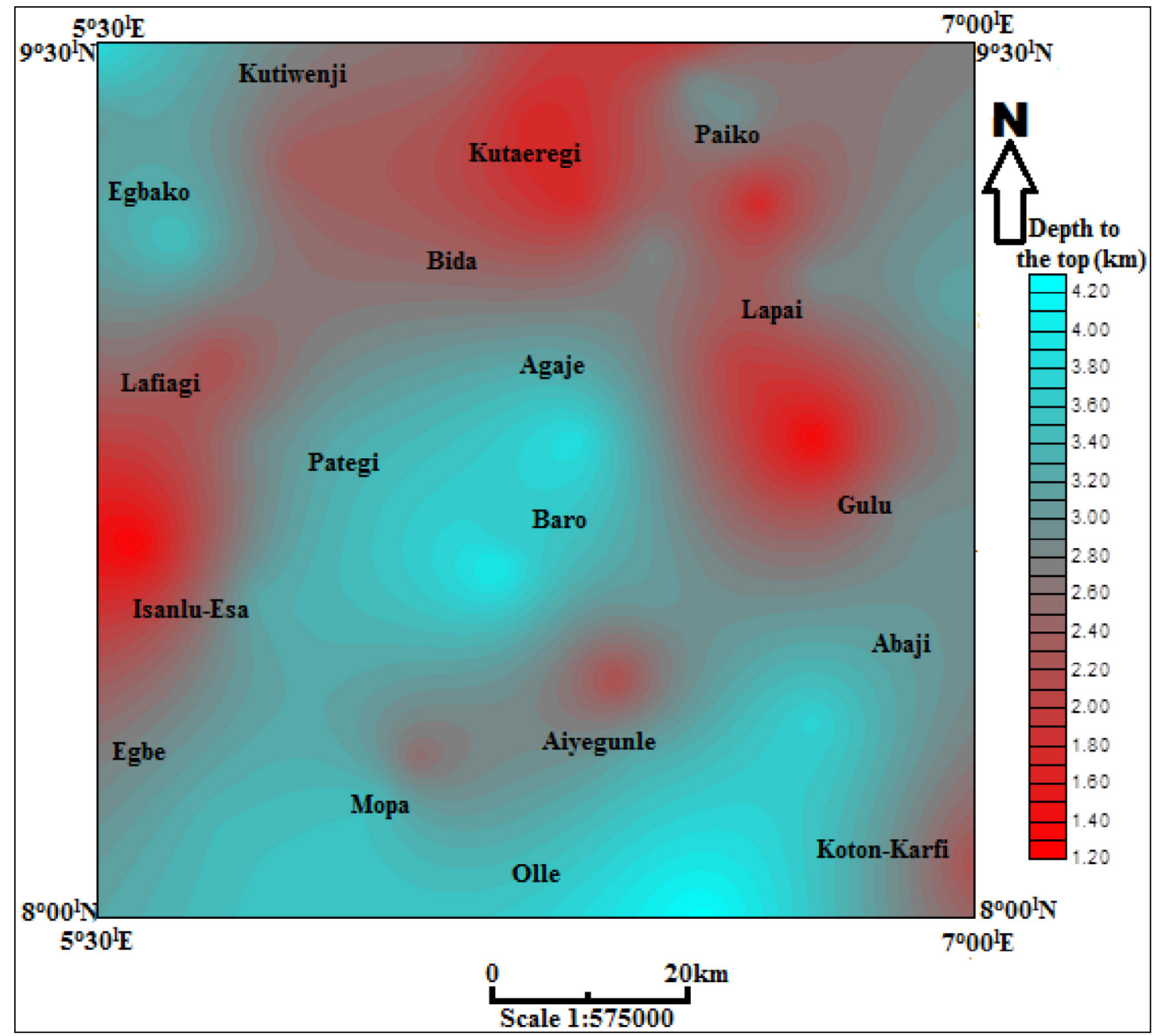

Figure 9- Depth to the top of the magnetic body in the area (contour interval $0.1 \mathrm{~m}$ ).

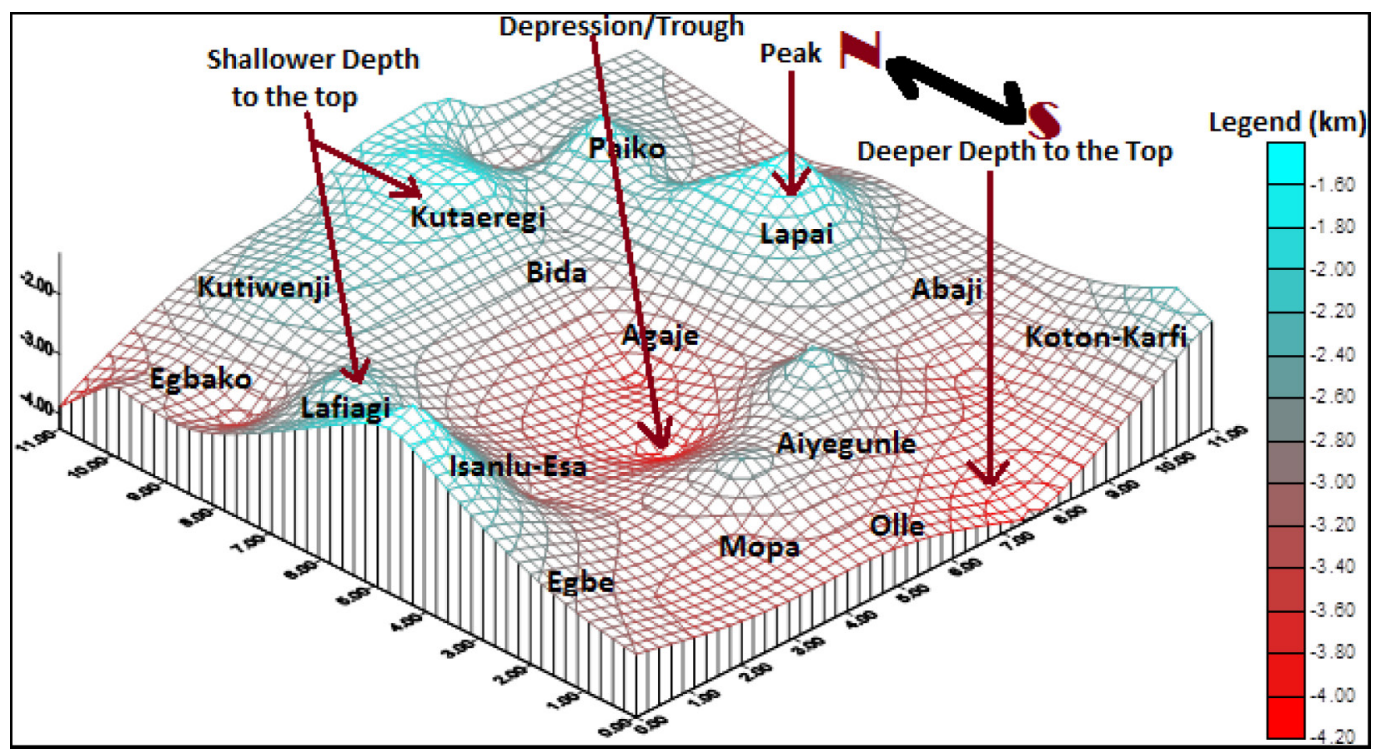

Figure 10- Real view model of depth to the top in the area. 
with depressional feature. According to Kogbe (1989), these identified igneous intrusives generally occur as silly and dykes.

\subsection{Computation of Thermomagnetic Properties}

\subsubsection{Curie Isotherm Depth}

The Curie isotherm depth result revealed deeper depth at Kutiwenji, Egbako, Lapai, Paiko, Olle, Mapo and Baro areas, ranging from 22.60 to $27.91 \mathrm{~km}$, in other parts, the Curie isotherm depth was shallower and ranged from 19.18 to $22.20 \mathrm{~km}$ (Table 1; Figure 11). The average depth to the Curie isotherm in the area is $23.12 \mathrm{~km}$. In addition, the 3 - D surface plot shows presence of uplifts and depressions across the study area (Figure 12). Around Kutiwenji, Egbako, Lapai, Paiko, Baro, Mopa, Agaje, and Olle areas, there are visible linear depressions and these areas reveal higher depth to the Curie point isotherm than the other parts such as Lafiagi, Isanlu - Esa, Gulu and Abaji areas which have prevalent uplifts (peaks) in conjunction with lower values (Figure 12). However, a scattered plot of depth to the top of basement and Curie depth across the study area depicts a direct relationship with a very poor correlation value of 0.1356 (Figure 13).

\subsubsection{Geothermal Gradient}

The result of the geothermal gradients obtained according to Tanaka et al. (1999) ranges between 21.98 and $30.95{ }^{\circ} \mathrm{C} / \mathrm{km}$ with an average of $25.27^{\circ} \mathrm{C} /$ $\mathrm{km}$ across the study area (Table 1). At Lafiagi Isanlu Esa, Egbe, Abaji and Gulu areas, geothermal gradient have relatively high geothermal gradient ranging between 25.76 and $30.95{ }^{\circ} \mathrm{C} / \mathrm{km}$ with total average of $25.27^{\circ} \mathrm{C} / \mathrm{km}$ (Figure 14) which compares favourably with average geothermal gradient of $23.56{ }^{\circ} \mathrm{C} / \mathrm{km}$ obtained within the Niger Delta by Emujakporue and Ekine (2014). More so, the 3-D surface plot shows

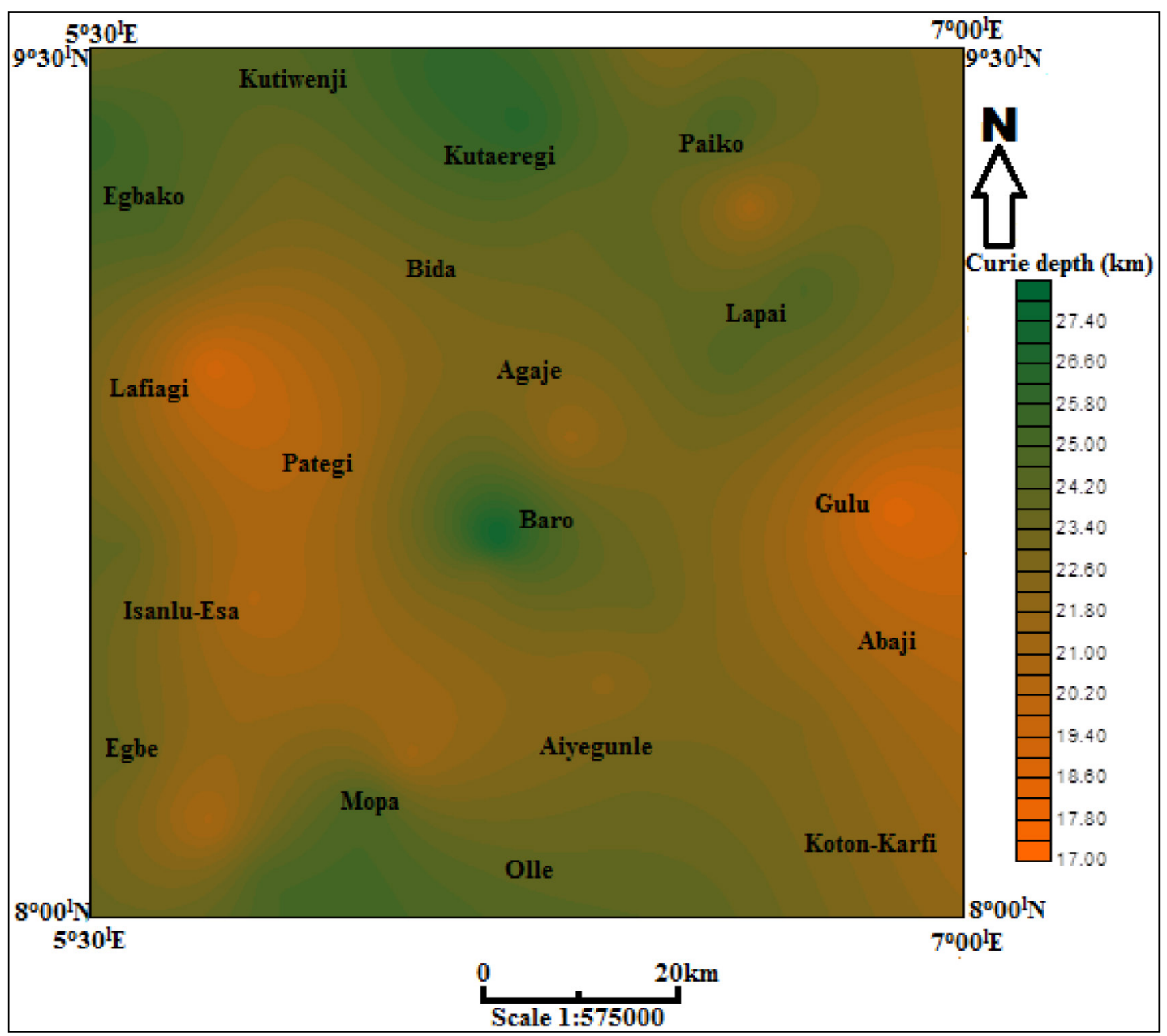

Figure 11- Curie depth map in the area (contour interval $0.4 \mathrm{~m}$ ). 


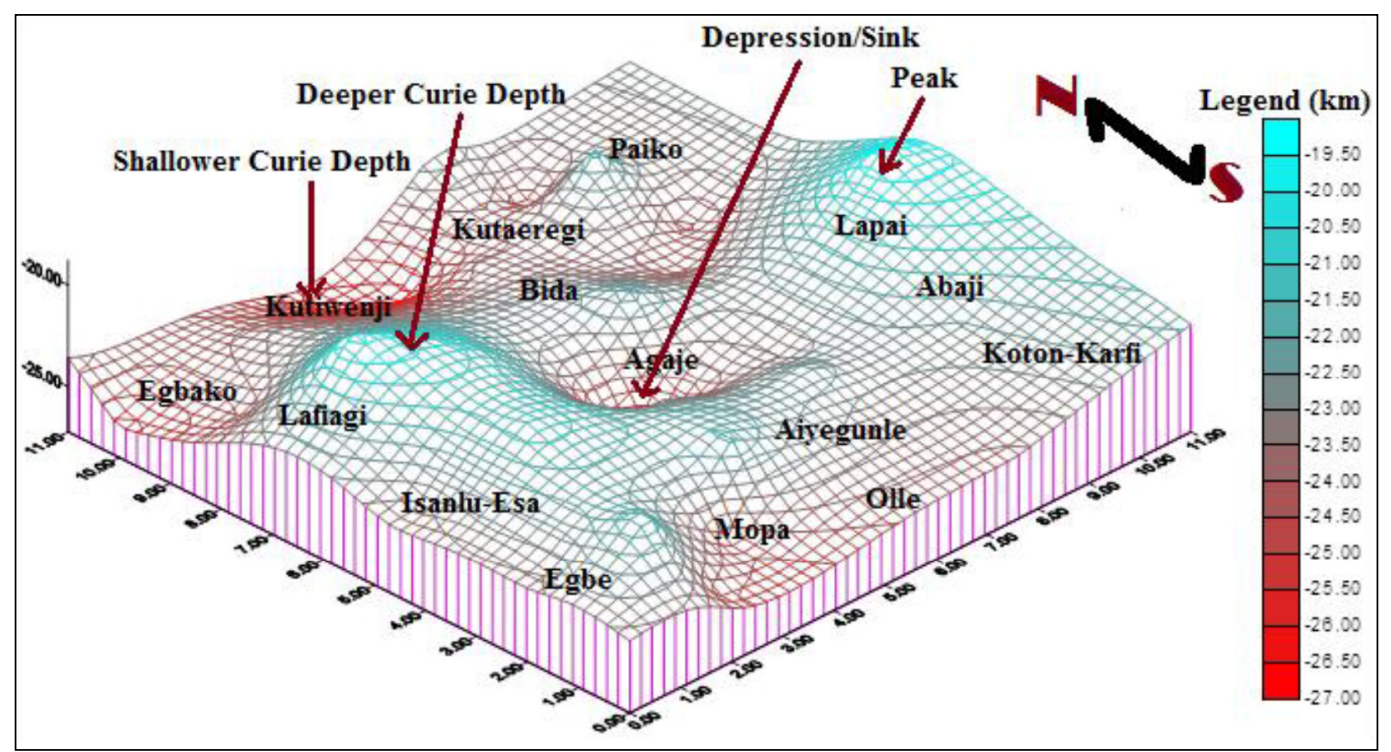

Figure 12- Real view model of Curie depth in the area.

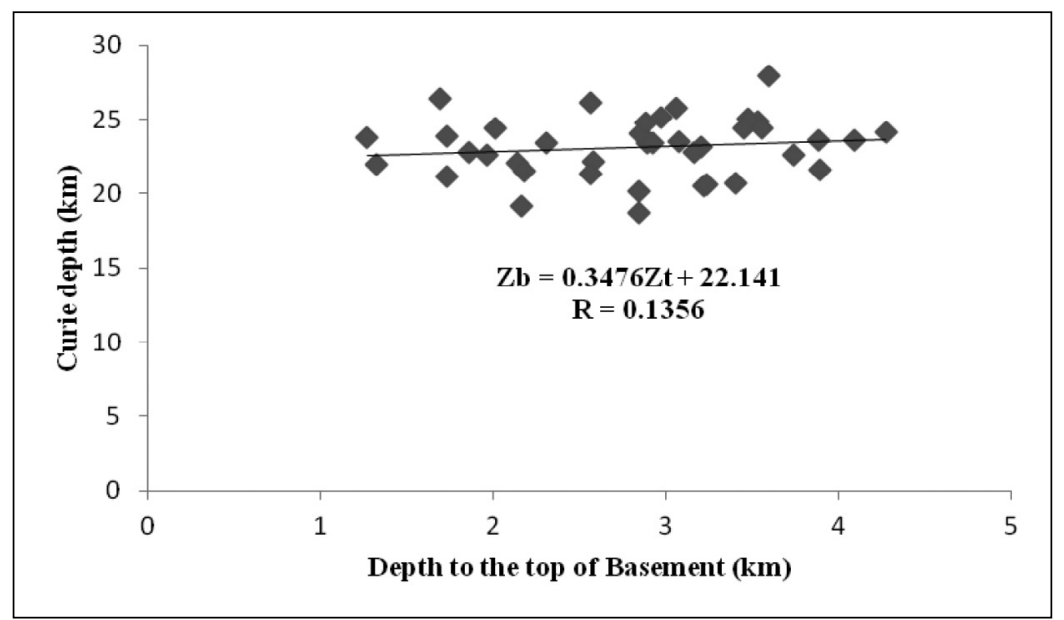

Figure 13- Comparison of basement relief and Curie depth in the area.

presence of uplifts and depressions across the study area (Figure 15).

\subsubsection{Heat Flow}

The result of the heat flow values obtained according to Tanaka et al. (1999) ranges between 51.95 and $77.37 \mathrm{mWm}^{2}$ with an average of 63.17 $\mathrm{mWm}^{2}$ across the study area (Table 1 ). The heat flow is lower around the northern and southern parts compared to the other areas within the study area (Figure 16). Furthermore, the 3 - D surface plot of the heat flow shows presence of peaks (uplifts) and depressions across the study area (Figure 17). Around
Lafiagi Isanlu - Esa, Egbe, Abaji and Gulu areas, there are visible linear depressions and these areas reveal higher geothermal gradient than the other parts such as Kutiwenji, Kutaeregi, Paiko, Lapai, Egbako, Mapo, and Olle areas which have prevalent uplifts (peaks) in conjunction with lower values (Figure 17).

\subsubsection{Correlation Between Curie Depth and Geothermal Gradient}

There is an inverse perfect relationship between Curie point isotherm and geothermal gradient across the study area with correlation value as approximately 1 (Figure 18). The designated areas of elevated 


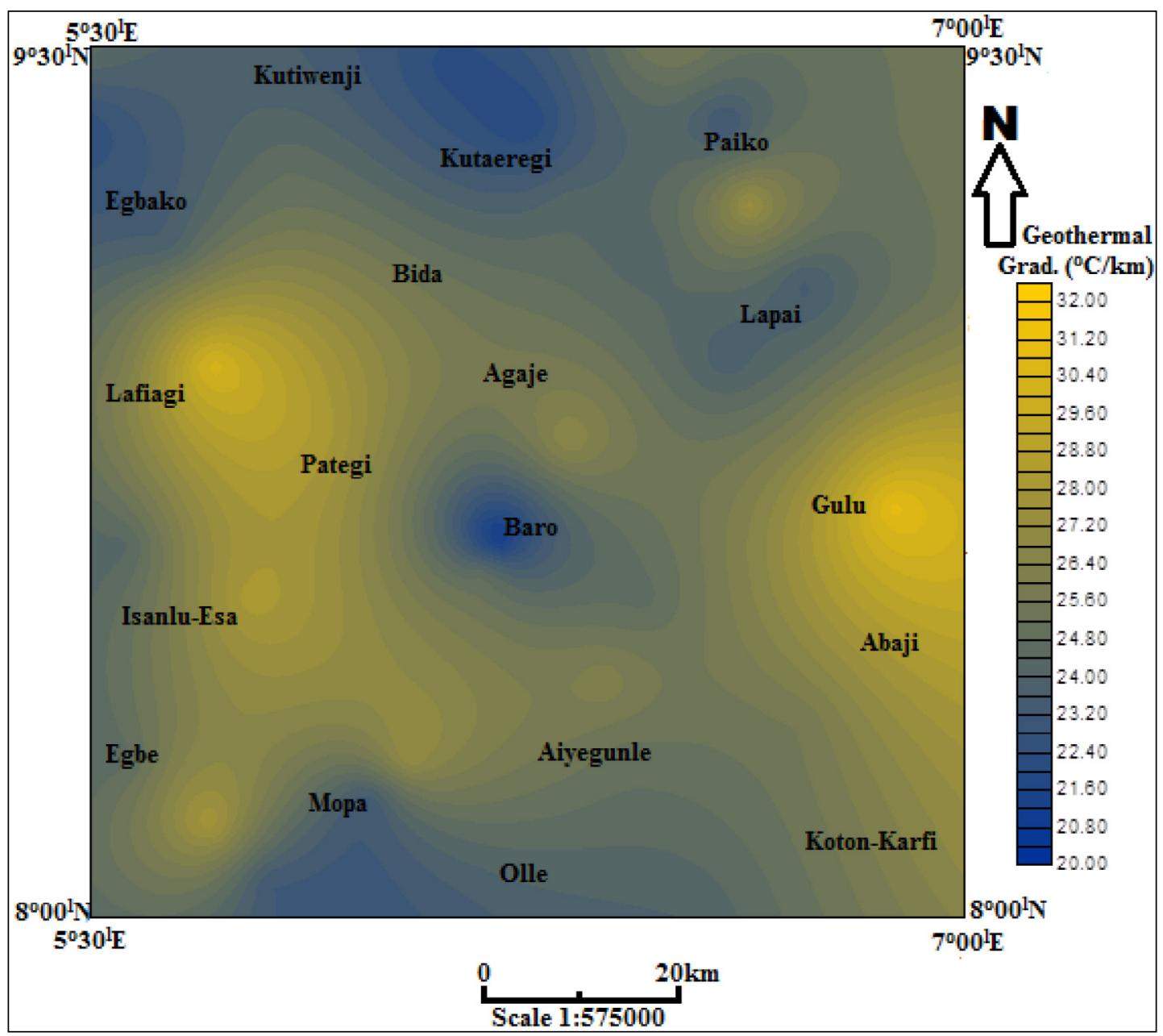

Figure 14- Geothermal gradient map in the area (contour interval $\sim 0.4^{\circ} \mathrm{C} / \mathrm{km}$ ).

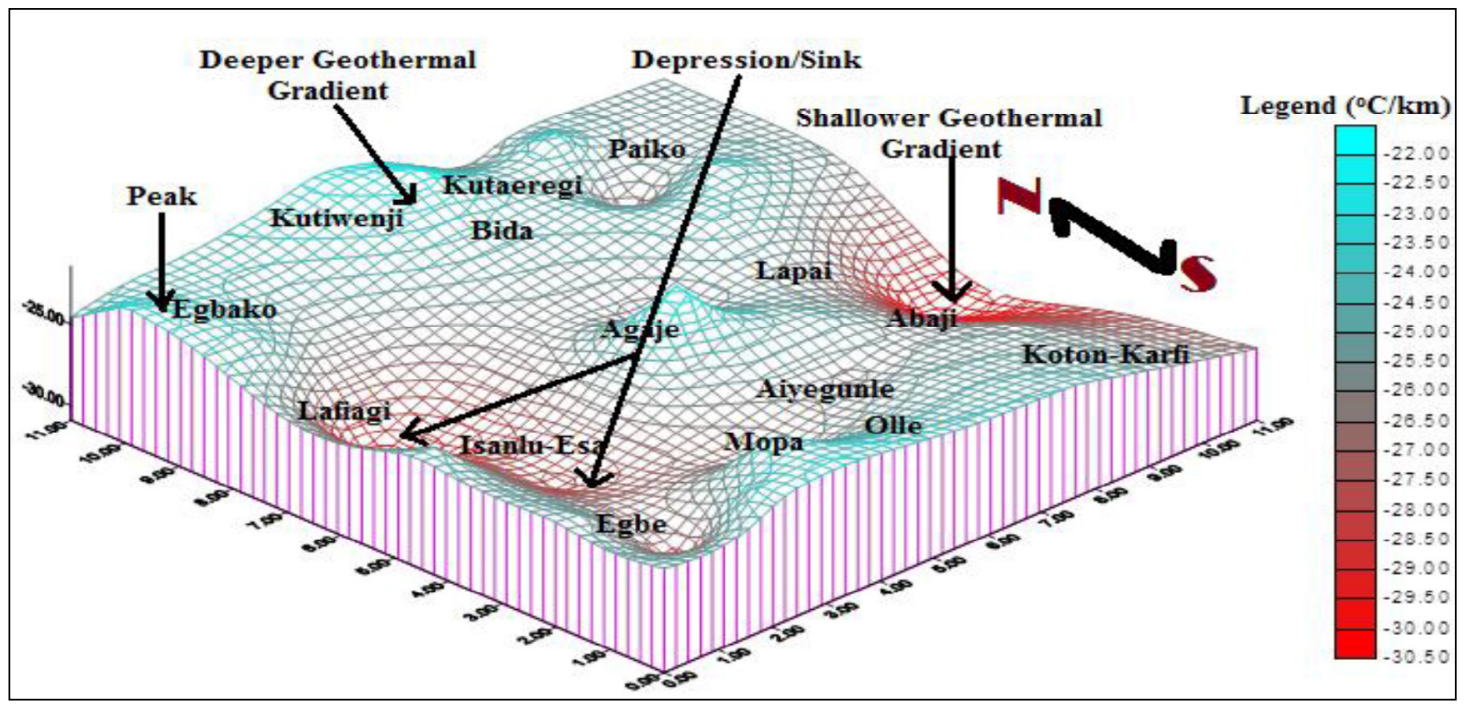

Figure 15- Real view model of geothermal gradient. 


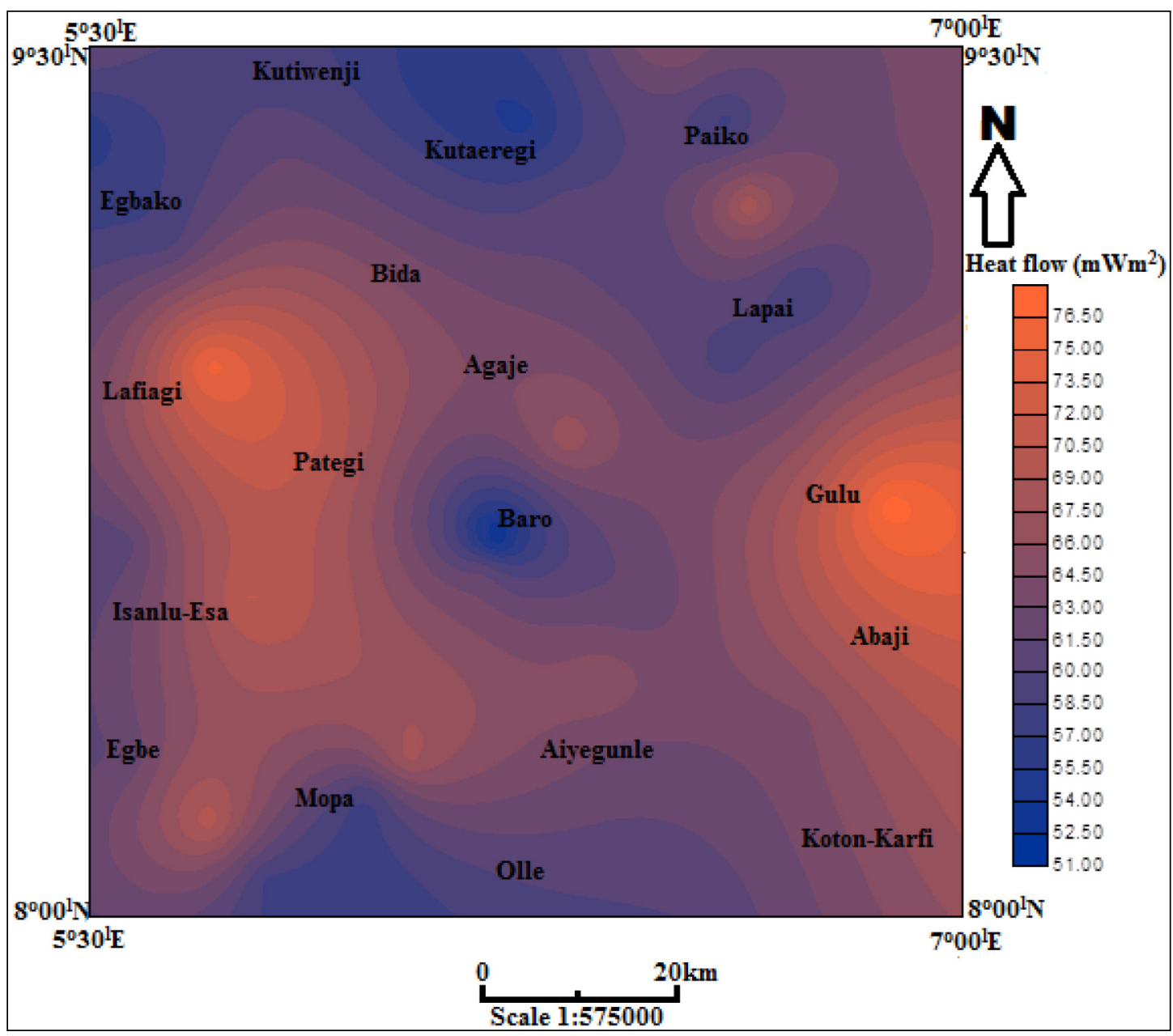

Figure 16- Heat flow map in the area (contour interval $\sim 1.5 \mathrm{mWm}^{2}$ ).

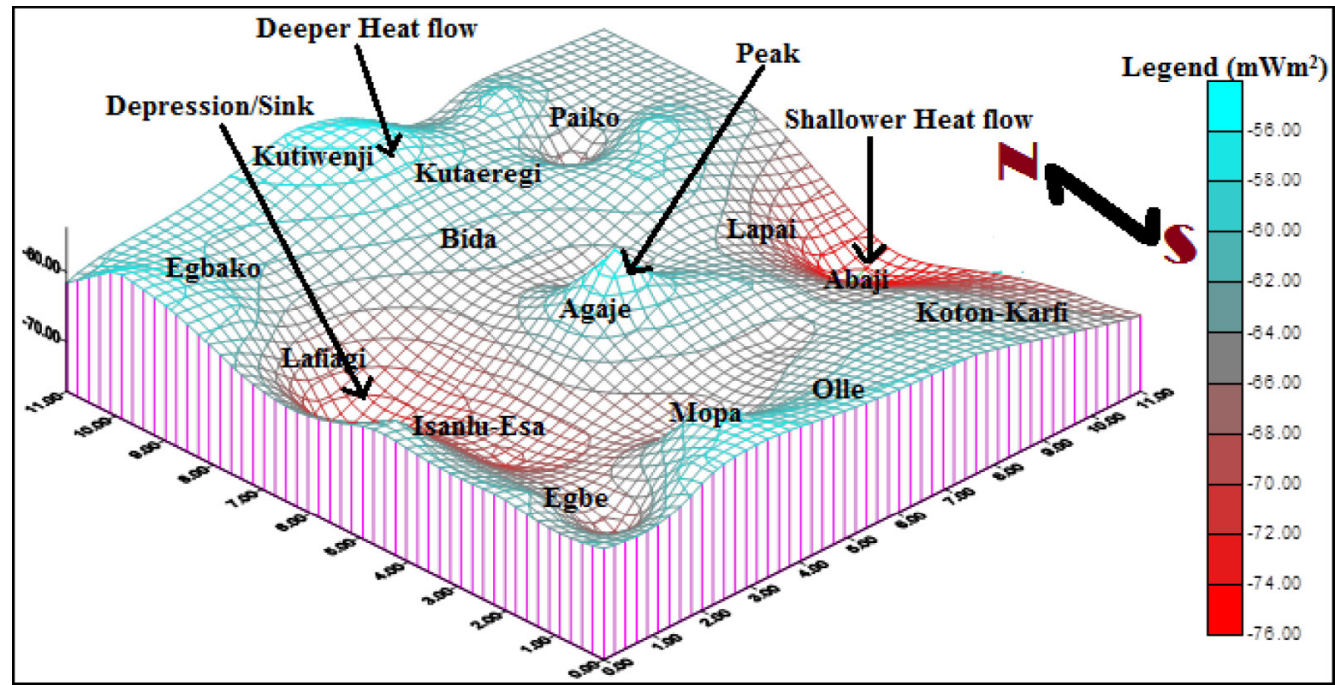

Figure 17- Real view model of geothermal gradient. 


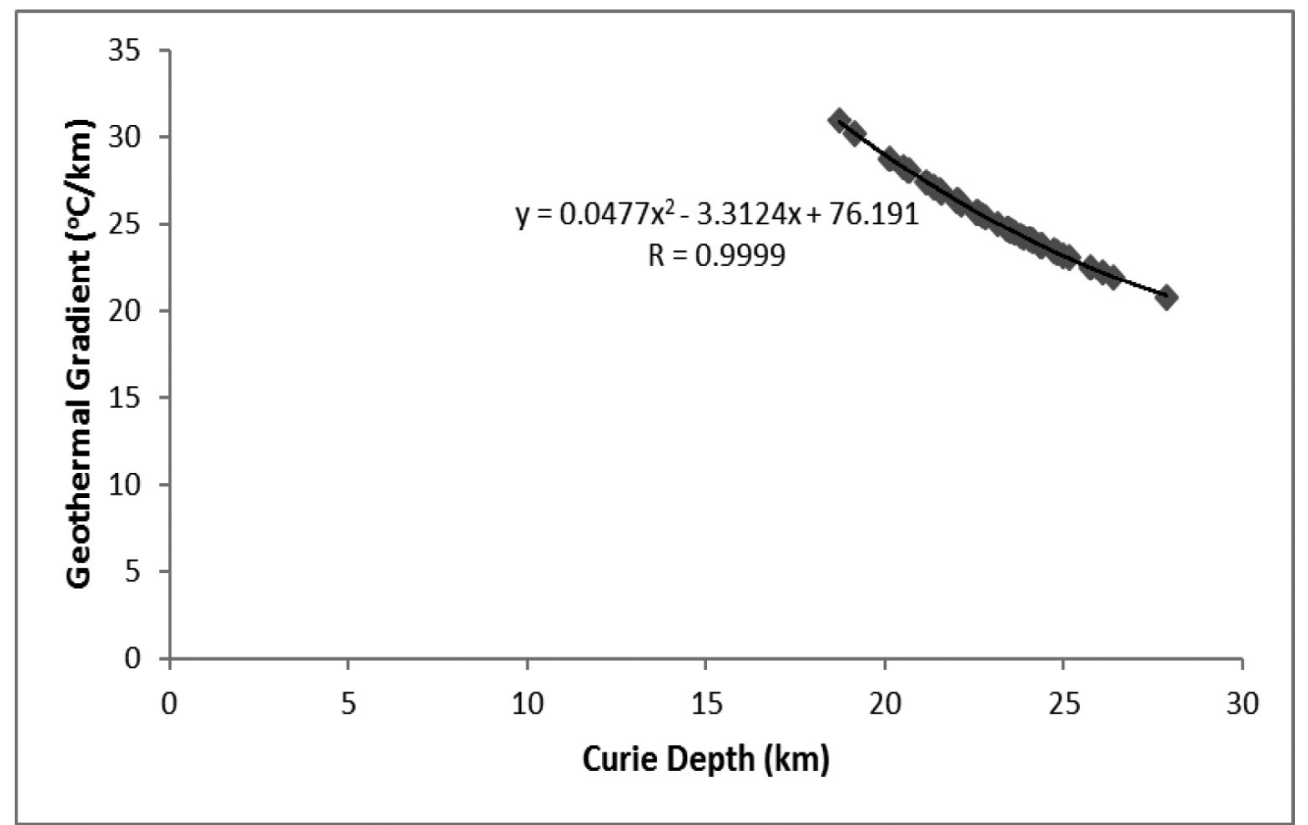

Figure 18- Relationship between Curie depth and geothermal gradient.

Curie point depth show considerable low geothermal gradient (Kutaeregi, Koton - Karfi as well as Baro). These areas have low sedimentary infillings (shallower depth to basement), while areas of low Curie point isotherm depth shows high geothermal gradient (Isanlu - Esa, Pategi and Aiyegunle). Some previous authors such as Nwankwo and Ekine (2010), Ikumbur et al. (2013) and Anakwuba and Chinwuko, (2015), believe that those sediments which were characterized by elevated values of geothermal gradients tend to mature earlier compared to those with low values of geothermal gradient.

\section{Discussion}

\subsection{Geothermal Energy Potentials and Its Implication}

The computed thermomagnetic properties according to Tanaka et al. (1999) showed average values of $23.12 \mathrm{~km}$ Curie isotherm depth, $25.27{ }^{\circ} \mathrm{C} /$ $\mathrm{km}$ geothermal gradients and $63.17 \mathrm{mWm}^{2}$ heat flows in the area (Table 1). These values indicated that the geothermal energy was of good quality. The values were used to generate a generalized map for possible area of geothermal energy exploration across the study area.

Moreover, integrating all the results and deductions obtained in this work, it can be deduced that these regions such as Lafiagi, Pategi, Bida, Baro,
Koton-Karfi, Egbe, Isanlu - Esa, Abaji, Paiko, and Agaje possess relatively high geothermal gradient and heat flow; which will possibly pave way for high geothermal energy potential in these areas (Figure 19), since at the far northeastern and southwestern parts of the area were covered by Basement rocks. But, there is low geothermal energy potential around Egbako, Kutiwenji, Kutaeregi, Lapai, Mopa, Olle and Aiyegunle (Figure 19). It is good to note that the geothermal energy deduced within the study area may have originated from the formation of the earth and possibly from decay of long - lived isotopes of uranium, thorium and potassium found within the basement complex rocks.

Generally, this study have shown that the geothermal energy sources are viable in those regions that were underlain by basement rocks and it is supported by previous researches conducted by Chukwu et al. (2017), Abraham et al. (2014), and Anakwuba and Chinwuko (2015). Despite this numerous abundance across our country, Nigeria, little or no attention has been paid to the chase for geothermal energy exploration. As a result, there has been a gap in thermomagnetic properties information within Nigeria and the study area is no exception. Furthermore, considering the environmental impact of petroleum products during and after exploration couple with decline in oil and gas production in 


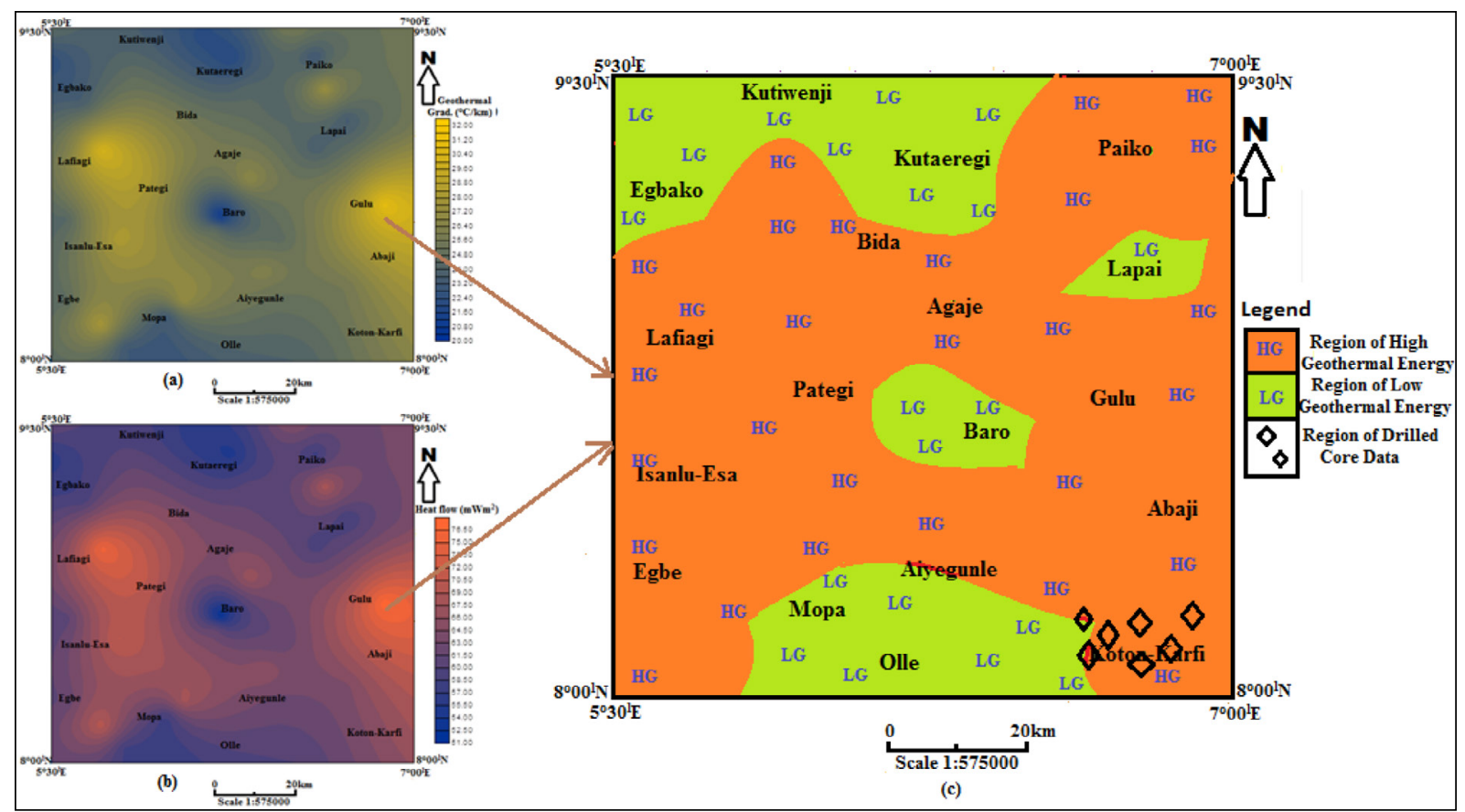

Figure 19- a) Geothermal gradient map in figure 14, b) Heat flow map in figure 16, and c) a potential map for possible geothermal energy across the study area.

our country, it has been necessary to explore this alternative source of energy called geothermal energy in order to meet our energy needs.

\section{Results}

The following conclusions have been reached after comprehensive analysis of magnetic anomalies:

1. The magnetic anomaly maps depict two prevalent structural features namely; uplift and depression, which are evidence of folding.

2. The lineament maps and Rose diagram produced signify that the study area is extremely faulted with prominent trends in NE - SW, whereas, the minor trends occur along E - W and NW - SE.

3. Two layers depth model were delineated: the shallower bodies varied from 1.27 to $1.96 \mathrm{~km}$; the deeper bodies vary from 2.01 to $4.27 \mathrm{~km}$.

4. The computed thermomagnetic properties showed average values of $23.12 \mathrm{~km}$ Curie isotherm depth, $25.27^{\circ} \mathrm{C} / \mathrm{km}$ geothermal gradients and $63.17 \mathrm{mWm}^{2}$ heat flows in the area. These values indicated that the geothermal energy was of good quality.
5. The computed results and models provided information on the capabilities of spectral analysis in delineating geothermal energy potentials and as such could be adopted to other areas with similar geologic framework in Nigeria and beyond.

\section{Acknowledgements}

The researchers are grateful to the National Geological Survey Agency, Abuja Nigeria, for their kind consent and endorsement to utilize the acquired nine aeromagnetic data for this research. In addition, we acknowledged the management of Federal College of Education Umunze, Nigeria for their permission and motivation during entire period of in this work.

\section{References}

Abraham, E. M., Lawal, K. M., Ekwe, A. C., Alile, O., Murana. K. A., Lawal, A. A. 2014. Spectral analysis of aeromagnetic data for geothermal energy investigation of Ikogosi warm Spring Ekiti state, Southwestern Nigeria. Geothermal Energy 26, 1-21.

Abraham, E. M., Obande, E. G., Mbazor, C., Chibuzo, G. C., Mkpuma, R. O. 2015. Estimating depth to the bottom magnetic sources at Wikki Warm Spring region, northeast Nigeria using fractal distribution 
of sources approach. Turkish Journal of Earth Science 24, 1-19.

Adeleye, D. R. 1974. Sedimentology of the fluvial Bida Sandstone (Cretaceous), Nigeria. Elsevier Journals of Sedimentary Geology 12(1), 1-24.

Anakwuba, E. K., Chinwuko, A. I. 2015. One dimensional spectral analysis and Curie depth isotherm of Eastern Chad Basin, Nigeria. Journal of Natural Sciences Research 5(19), 14-22.

Anudu, G. K., Onuba, L. N., Onwuemesi, A.G., Ikpokonte, A.E. 2012. Analysis of aeromagnetic data over Wamba and its adjoining areas in north-central Nigeria. Earth Sciences Research Journal 16(1),25-33

Burke, K. 1972. Longshore Drift, submarine canyons and submarine fans in development of Niger delta. American Association of Petroleum Geologist Bulletin 56, 1975-1983.

Biswas, A. 2015. Interpretation of residual gravity anomaly caused by a simple shaped body using very fast simulated annealing global optimization. Geosciences Frontiers 6(6), 875-893.

Biswas, A., Sharma, S. P. 2016. Integrated geophysical studies to elicit the structure associated with Uranium mineralization around South Purulia Shear Zone, India: A Review. Ore Geology Reviews 72, 1307-1326.

Biswas, A., Parija, M. P., Kumar, S. 2017. Global nonlinear optimization for the interpretation of source parameters from total gradient of gravity and magnetic anomalies caused by thin dyke. Annals of Geophysics 60(2), 1-17.

Bhattacharyya, B. K. 1966. Continuous spectrum of the magnetic field anomaly due to a rectangular prismatic body. Geophysics 31, 121.

Bhattacharyya, B. K., Leu, L. K. 1975. Spectral analysis of gravity and magnetic anomalies due to dimensional structures. Geophysics 40, 993-1031.

Chinwuko, A. I., Onwuemesi, A. G., Anakwuba, E. K., Onuba, L. N., Nwokeabia, N. C. 2012. The interpretation of aeromagnetic anomalies over parts of Upper Benue Trough and southern Chad Basin, Nigeria. Advances in Applied Science Research 3(3), 1757-1766.

Chinwuko, A. I., Usman, A. O., Onwuemesi A. G., Anakwuba, E. K., Okonkwo, C. C., Ikumbur, E. B. 2014. Interpretations of aeromagnetic data over Lokoja and environments, Nigeria. International Journal of Advanced Geosciences 2(2), 66-71.

Chukwu, C. G., Udensi, E. E., Abraham, E. M., Ekwe, A. C., Selemo, A. O. 2017. Geothermal energy potential from analysis of aeromagnetic data of part of the
Niger-delta basin, southern Nigeria. Energy 143, 846-853.

Emujakporue, G. O., Ekine, A. S. 2014. Determination of geothermal gradient in the Eastern Niger Delta Sedimentary Basin from bottom hole temperatures, Journal of Earth Sciences and Geotechnical Engineering 4(3), 109-114.

Frashëri, A., Alikaj P., Frashëri, N. 2011. Some survey and interpretation problems on IP method. $6^{\text {th }}$ Congress of Balkan Geophysical Society, Budapest, Hungary, 22.

Ikumbur, E. B., Onwuemesi, A. G., Anakwuba, E. K., Chinwuko, A. I., Usman, A. O., Okonkwo, C. C. 2013. Spectral analysis of aeromagnetic data over part of the southern Bida basin, West-Central Nigeria. International Journal of Fundamental Physical Sciences 3(2), 27-31.

Kogbe, C. A. 1989. The Cretaceous and Paleogene sediments of Southern Nigeria. Geology of Nigeria ( $2^{\text {nd }} \mathrm{Ed}$.). Rock View Ltd. Nigeria, 538.

Mandal, A., Biswas, A., Mittal, S., Mohanty, W. K., Sharma, S. P. Sengupta, D., Sen, J., Bhatt, A. K. 2013. Geophysical anomalies associated with uranium mineralization from Beldih mine, South Purulia shear zone. Journal Geological Society of India 82(6), 601-606.

Nwankwo, C. N., Ekine, A. S. 2010. Geothermal gradients in the Chad Basin, Nigeria, from bottom hole temperature logs. Scientia Africana 9(1), 37- 45.

Obaje, N. G., Balogu, D. O., Idris - Nda, A., Goro, I. A., Ibrahim, S. I., Musa, M. K. Dantata, S. H., Yusuf I., Mamud- Dadi, N., Kolo I. A. 2013. Preliminary integrated hydrocarbon prospectivity evaluation of the Bida Basin in North Central Nigeria. Petroleum Technology Development Journal 3(2), 36-65.

Ojo, O. J., Akande, S. O. 2012. Sedimentary facies relationships and depositional environments of the Maastrichtian Enagi Formation, Northern Bida Basin, Nigeria. Journal of Geography and Geology 4(1), 136-147.

Ojonugwa, U. A., Ezeh, C. C., Chinwuko, I. A. 2018. Integration of aeromagnetic interpretation and induced polarization methods in delineating mineral deposits and basement configuration within Southern Bida Basin, North-West Nigeria. Journal of Geology and Geophysics 7, 449-454.

Okubo, Y. J., Graf, R., Hansen, R. O., Ogawa, K., Tsu, H. 1985. Curie point depth of the Island of Kyushu and surrounding areas. Japan Geophysics 53, 481491. 
Okonkwo, C. C., Onwuemesi, A. G., Anakwuba, E. K., Chinwuko, A. I., Ikumbur B. E. and Usman, A.O. 2012. Aeromagnetic interpretation over Maiduguri and environments of Southern Chad Basin, Nigeria. Journal of Earth Sciences and Geotechnical Engineering 2(3), 77-93.

Onwuemesi,A. G. 1995. Interpretation of magnetic anomalies from the Anambra Basin of Southeastern Nigeria. Ph.D Thesis, Nnamdi Azikiwe University, Awka, Nigeria.

Onwuemesi, A. G. 1997. One dimensional spectral analysis of aeromagnetic anomalies and curie depth isotherm in the Anambra Basin of Nigeria. Journal of Geodynamics 23(2), 95-107.

Pamukçu, O., Akçı̆̆ Z., Hisarlı, M., Tosun, S. 2014. Curie point depths and heat flow of eastern Anatolia (Turkey). Energy Sources, Part A: Recovery, Utilization, and Environmental Effects 36(24), 2699-2706.

Petters, S. W. 1978. Stratigraphic evolution of the Benue Trough and its implications for the Upper Cretaceous paleogeography of West Africa. Journal of Geology 86, 311-322.
Ross, H. E., Blakely, R. J., Zoback, M. D. 2006. Testing the use of aeromagnetic data for the determination of Curie depth in California. Geophysics 71(5), 5159.

Saibi, H, Aboud, E., Azizi, M. 2015. Curie point depth map for Western Afghanistan deduced from the analysis of aeromagnetic data, Proceedings World Geothermal Congress 2015, Melbourne, Australia, 19-25.

Singh, A., Biswas, A. 2016. Application of global particle swarm optimization for inversion of residual gravity anomalies over geological bodies with idealized geometries. Natural Resources Research 25(3), 297-314.

Spector, A., Grant, F.S. 1970. Statistical models for interpretation of aeromagnetic data. Geophysics 35, 293-302.

Tanaka, A. Y., Okubo, Y., Matsubayashi, O. 1999. Curie point depth based on spectrum analysis of the magnetic anomaly data in East and Southeast Asia. Tectonophysics 396, 461-470. 